\title{
MACRO COHERENCE LEVEL ON STUDENTS' SCIENTIFIC PAPER
}

\author{
Leora G. Andovita ${ }^{\left.a^{*}\right)}$, Aceng Rahmat ${ }^{b)}$, Hanif Pujiati ${ }^{b)}$ \\ a) Pakuan University, Bogor, Indonesia \\ ${ }^{b)}$ Universitas Negeri Jakarta, Jakarta, Indonesia \\ *) Corresponding Author: leora.andovita@unpak.ac.id
}

Article history: received 19 August 2019; revised 31 August 2019; accepted 16 September2019

\begin{abstract}
Purposely contemplating at seventh semester students of English Education Study Progam, it is perceived that students exhibit a lack of skills in use of rhetoric, predominantly making errors in the use of words and phrases, directly translating words from Bahasa Indonesia to English - interlanguage error - and organizing their written text inadequately. Moreover, it is discovered that the viewpoints of the students frequently shift. To address this, this current study aims at investigating students' macro-level coherence in their academic writing (henceforth; background of the study of a research proposal). A content analysis is applied including documents. Additionally, a descriptive analysis design is used to guide this study. There are six research proposals investigated to gain the data of this study. These proposals are taken purposively sampled from proposals submission from early 2018 intake. There are two main frameworks in this study. Firstly, the academic writing guidance book is used to analyze the rhetoric/organization of the paper. Secondly, the coherence analysis is applied to evaluate students' coherence level. Analysis of findings shows that students encounter some problems in the coherence of English research proposal writing. Hence, it is argued that close attention should be paid to the refinement and suitable tutoring of coherence in the teaching of academic English writing.
\end{abstract}

Keywords: macro-level coherence; students' english reasearch proposal writing; content analysis

\section{INTRODUCTION}

Writing English-language scientific papers is still considered difficult for 7 th semester students of the English Education Study Program at the Faculty of Teacher and Educational Sciences, Pakuan University. One part of the writing of the scientific work is the proposal part that plays an important role in conveying the topic of research problems. However, what happens is that the sentences written do not show a logical relationship and the text structure of the writing of the Background Problem is not appropriate. The idea to be conveyed might have been well thought out but when transforming the idea into writing in English it would not necessarily be as good as the idea you have in mind. Therefore, the interrelationships between the paragraphs in the writing must originate from the same main idea.

One of the factors that can affect this obstacle is mothertongue interference. The concept that comes to mind in the form of words in Indonesian, but when writing it must be changed into an English concept that is different from the concept of the Indonesian language. The use of words or phrases as connectors between sentences and paragraphs in writing also experiences errors so that the ideas in the writing become unified.

Readability of a text so that it can really be accepted is influenced by cohesion and coherence. The coherence elements in the text serve to show the interrelationship between ideas between paragraphs and paragraphs. With these elements of coherence, it can help the reader understand the statements or opinions written by the author. If in a paper there is a clash of ideas between paragraphs in paragraphs or between paragraphs, then the writing will not be coherent.

Although students have started writing simple texts since semester 2, they still experience difficulties when in semester 7 writing scientific papers such as essays and thesis proposals. Since semester 2, they have only been accustomed to writing fiction essays and reading fiction texts. So they are not familiar with the model of writing scientific papers and this makes them experience problems when writing a thesis proposal. Though the activity of writing a thesis proposal must be done as a final project in the Academic Writing course. One part of the thesis proposal is the background writing of the topic to be examined. The ideas that they put in writing have begun to vary, but not yet neatly arranged. This can be caused by their consideration to put any ideas in mind at that time before they forget the material. Therefore, there is overlap or incongruity in the interrelationship relationship between paragraphs and paragraphs. The occurrence of non-integration of student writing can make it difficult for readers to understand the purpose of writing itself. Ideas that have not been coherent cause the writing is incoherent.

The integrity of a text is influenced by cohesiveness or coherence between paragraphs and paragraphs that refer to the same idea so that the written text is acceptable. For a paragraph to be coherent, the paragraph must meet two criteria, namely: relevance and logical order (effective order)

The problem of the cohesiveness of this text has received much attention from researchers as conducted by Astuti, Suryani, and Kurniati [1] questioning the coherence of the writing background of student thesis research. Coherence is very necessary when writing research background so that the integrity of a text can be achieved. 
However, students still find it difficult to maintain the cohesiveness of the text. There are three things that are the focus of research: (1) the types of themes in the background of the thesis, (2) the thematic progression, and (3) the level of background writing coherence. The results of the study show: (1) topical theme is the most frequent category of themes, (2) the thematic progression in the background of the thesis is not constant because there is a change in the type of thematic progression in almost every new paragraph, and (3) the level of coherence writing background of the thesis is less (less coherence) because of the emergence of other new ideas in one paragraph.

Liyana [2] found four things related to cohesion and coherence. First, the use of both grammatical cohesion tools, which consists of references, substitution, ellipsis, and conjunctions, and lexical cohesion tools, which consist of reitration and collocation. Secondly, errors in the use of cohesion tools are only found in reference and conjunction grammatical cohesion devices. Third, the use of coherence markers, which consist of repetition of keywords, use of pronouns, transition markers and logical sequences in the form of chronology. Fourth, errors in the cause of the lack of coherent thesis, consisting of repetition of keywords, inconsistent pronominal errors, errors of transition markers, grammatical errors, and improper use of punctuation. Fifth, the student's thesis when viewed from the principles applied in the thesis can be said to be coherent in terms of the use of language that is concise, polite, coherent and objective. However, it can be said to be incoherent in terms of using language that is complete, honest, straightforward, and interesting. Fengjie, Xiuying, and Chuanze [3] focused research on the level of coherence of student essay writing. The results show that students still cannot write sentences effectively. The use of word sequences, pronouns, modifiers, sequence of ideas, sentence subjects, and tenses has not shown any integrated information integration. This is caused by: (1) lack of self-awareness in getting used to writing in English; (2) limited English vocabulary; (3) weaknesses in the use of English grammar; (4) lack of self-awareness to correct and learn from mistakes when writing. Then based on the results of this study, the researchers concluded that although students could express their ideas in written form, they could not write them with effective sentences. Research conducted by Fengjie et al [3] has not yet examined the use of conjunctions, so further research is needed on the object / focus. This is based on the condition of students who still use a lot of conjunctions that are not in accordance with the function that they should.

Referring to the studies above that show the results of the research are still found to be the inability of students to combine sentences to be coherent, and difficulty in expressing ideas or ideas in writing a coherent paragraph and inaccurately in using conjunctions, further research is needed to determine the level of understanding coherent use of words in a writing. The research conducted has not yet examined the use of conjunctions, so further research is needed on the object / focus. This is based on the condition of students who still use a lot of conjunctions that are not in accordance with the function that they should. The fact that the script proposal written by students still does not meet these criteria, raises the author's curiosity about the coherence of students, especially in writing the thesis proposal.

Writing effective paragraphs cannot be done with just one write. Writing a paragraph or text needs to go through a process. The term coherence according to Reid [4] implies cohesion or affinity. Coherence means to stick together. This shows that there are strands of ideas intertwined so that the ideas that emerge can be continuous. The string of ideas was said by Zemach and Rumisek [5] arranged clearly and in their logical order. Ideas expressed in logical order can show the clarity of the context of a paragraph. Emilia [6] states, "coherence refers to the way a group of clauses or sentences relates to the context."

Coherence in the research journal Anjani [7] is said to be a slick and true discourse. In other words, coherence is defined as a series of ideas arranged with order and logic. Coherence can occur implicitly because it is related to the meaning interpreted by the reader. Various kinds of relations between parts in a coherent discourse can be in the form of causal, sequential, resistance, over, sum, time, conditions, methods, uses, and explanations. Each of the inter-section relations has certain coherence markers in the appointment of coherent questions.

Meanwhile in the research journal Itaristanti [8] stated that coherence is a logical relationship between one sentence with another sentence in an essay or discourse. Kushartanti [9] revealed that coherence is the acceptance of a speech or text because of its semantic cohesion.

Opinions about this coherence were also expressed by Tanskanen [10] that "Coherence can be perceived and communication is more likely to be successful if the receiver's background knowledge is sufficient for making an interpretation". Thus coherence can be felt and communication is more likely to succeed if the background knowledge of the recipient is sufficient to make an interpretation.

A description of the coherence can be synthesized that coherence is a cohesion in a clear, logical, and systematic sentence and all parts of the sentence are interrelated with the meaning of mutual binding. Coherence is not only shown in the relationship between sentences in one paragraph, but also between paragraphs so that the reader can see the interrelationship between the ideas of each paragraph. Coherence can be seen from two levels, namely micro-level coherence and macro-level coherence. Microlevel coherence is a level based on logical relationships between sentences. The logical relationship between sentences shows how the whole text - even short texts becomes coherent because basically coherence is a series logically arranged facts and ideas. Macro-level coherence is related to a topic or theme text that shows something that is discussed in the text. On this macro-level, paragraph or text is declared coherent if appropriate with rhetorical steps and the type of text written. So, communicative purpose of the text can be understood. 


\section{RESEARCH METHODS}

The research method used is content analysis aimed at finding facts about the level of coherence that comes from the scientific work of FKIP Unpak English Education Study Program students. The design of this study is descriptive analysis, the researcher will describe the data source along with a critical analysis of the data source. The design of this research will be able to describe the level of coherence in the background section of the problem in the student thesis proposal

Data collection techniques used in this study are documentation techniques. This technique is used by researchers to obtain data sources in the form of scientific work in the form of student thesis proposals written in Academic Writing courses. Data obtained from the study were then analyzed in stages. The analysis is used through three stages:

1. Data Reduction : Reduced research data is data derived from documents containing the level of coherence in the student thesis proposal, which includes the cohesiveness of the relationships between sentences in paragraphs and between paragraphs and the suitability of texts written by students with the organizational structure of types of texts of scientific work.

2. Data Display : In this study the data presented are the results of the data on the level of coherence of relationships between sentences in paragraphs and between paragraphs in scientific papers written by students, especially the Background of the Study in the thesis proposal as well as the suitability of the text they write with the organizational structure of the type of scientific work text.

3. Conclusion drawing : Interesting conclusions are made by reviewing the results of research notes. Then, this conclusion will show the level of coherence of the relationship between sentences in paragraphs and between paragraphs and find out the suitability of the organizational structure of types of texts of scientific work with texts written by students.

\section{RESULTS AND DISCUSSION}

Writing student thesis proposals is done by paying attention to the text structure of scientific writing. In this study, the structure of the analyzed text is the background section written by 7 th semester students on the thesis proposal. Section background research problems play an important role in writing any scientific work, including writing a thesis proposal. The description of the background of the research is systematically structured information which aims to explain the reasons why the problem in the research is to be investigated, the importance of the problem and the approach used to solve the problem both theoretically and practically.
This section consists of four components that can provide an overview of the research to be carried out. The four components are a description of the problem / phenomenon / issue underlying the research, a description of the gap between what happens in the field and theoretical studies, a description of the significance of research, and the research problems / phenomenon / issues that are related to the field under study. By following the writing component, students will produce comprehensive background writing.

The findings analyzed from the six research proposals, each component can be seen in the following table 1 .

Tabel 1. Research Findings

\begin{tabular}{|c|c|c|c|c|c|}
\hline \multirow[b]{2}{*}{ Titles } & \multicolumn{4}{|c|}{ Findings } & \multirow[b]{2}{*}{ Note } \\
\hline & $\begin{array}{c}\text { Description of } \\
\text { the research } \\
\text { issue/problem }\end{array}$ & Gap & $\begin{array}{c}\text { Research } \\
\text { Significance }\end{array}$ & $\begin{array}{c}\text { Research } \\
\text { problem } \\
\text { statement }\end{array}$ & \\
\hline $\begin{array}{l}\text { Student's Interestin } \\
\text { Leaming English } \\
\text { Using Hot Potatoes }\end{array}$ & Paragraph1 & - & $\begin{array}{l}\text { Paragraph3, } \\
4 \text {, dan } 5\end{array}$ & - & \multirow{6}{*}{$\begin{array}{l}\text { Students still } \\
\text { do not fully } \\
\text { understand } \\
\text { the aspects } \\
\text { or } \\
\text { components } \\
\text { that should } \\
\text { be in the } \\
\text { proposal }\end{array}$} \\
\hline $\begin{array}{l}\text { The Use of 'Flash } \\
\text { Card' on Students' } \\
\text { Understanding } \\
\text { about Simple Past } \\
\text { Tense }\end{array}$ & $\begin{array}{l}\text { Paragraph1 } \\
\text { dan2 }\end{array}$ & $\begin{array}{l}\text { Paragraph } \\
3\end{array}$ & - & - & \\
\hline $\begin{array}{l}\text { English Nedeed by } \\
\text { Copy Editor }\end{array}$ & $\begin{array}{l}\text { Paragraph1 } \\
\text { dan2 }\end{array}$ & $\begin{array}{l}\text { Paragraph } \\
3\end{array}$ & $\begin{array}{l}- \\
-\end{array}$ & $\begin{array}{l}- \\
-\end{array}$ & \\
\hline $\begin{array}{l}\text { Lexical Semantic } \\
\text { Errors in Students' } \\
\text { Writing, }\end{array}$ & $\begin{array}{l}\text { Paragraph1,2, } \\
\text { dan3 }\end{array}$ & $\begin{array}{l}\text { Paragraph } \\
3\end{array}$ & - & $\begin{array}{l}\text { Paragraph } \\
6\end{array}$ & \\
\hline $\begin{array}{l}\text { The Role of Google } \\
\text { Translate in } \\
\text { Translating } \\
\text { Indonesian Text } \\
\text { Into English }\end{array}$ & $\begin{array}{l}\text { Paragraph1 } \\
\text { dan2 }\end{array}$ & - & - & $\begin{array}{l}\text { Paragraph } \\
3\end{array}$ & \\
\hline $\begin{array}{l}\text { The Application of } \\
\text { Phrasal Verb in } \\
\text { Writing Paragraph }\end{array}$ & Paragraph1 & $\begin{array}{l}\text { Paragraph } \\
2 \text { dan3 }\end{array}$ & 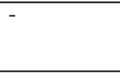 & $\begin{array}{l}\text { Paragraph } \\
3\end{array}$ & \\
\hline
\end{tabular}

Background of the study is information arranged systematically with respect to interesting phenomena and problems to be studied. Problems occur when the ideal expectations for something are not the same as the reality that occurs. Not all problems can be said to be phenomenon and interesting. A phenomenal problem occurs when it comes to the attention of many people and is discussed in various circles in the community. The background writing is intended to explain the reasons why the problem in research is to be investigated, the importance of the problem and the approach used to solve the problem both in terms of theoretical and practical.

Macro level coherence analysis is done by analyzing the suitability of the structure of the background text of the problem contained in the student thesis proposal. The structure of the text to be analyzed must contain a description of the problem / phenomenon / issue underlying the research, a description of the gap between what is happening in the field and a theoretical study, a description of the significance of the research and the formulation of the research problem / phenomenon / issue associated with the field being studied.

Writing a thesis proposal, must begin with an introduction that clearly states the problem so that it can provide information about why the problem is worthy of research. Readers according to Behrens and Rosen [11] must be able to understand the intent of the author in the background because in this section the writer discusses an 
issue according to its context. The author expresses his opinion on a topic that is in accordance with the reality that occurs so that the opinion can be considered valid. Then according to Winkler and Matherell [12] argues that statements about information are written in the background with short sentences, easy to understand, and have an idea that makes the reader think in the direction of what the writer wants. Therefore, statements that show the context or situation that is the author's motive should not be presented protracted.

Research on this coherence has been done before by other researchers, including Suwandi [13] who examined the level of coherence and cohesion in writing thesis abstracts at PGRI Semarang University students. The study focused on the level of macro and micro coherence by using theme adolescent analysis. The results of the study showed that the abstract writing was not integrated. In the three abstracts there are conjunction words that are used, but not in accordance with their functions, so that the sentence is not coherent. Kelvin's research has similarities in the focus of research, namely macro and micro level coherence, but different on the object under study, namely abstract writing on student thesis.

Then Astuti, Suryani, and Kurniati [1], who examined the Analysis of Coherence in Writing the Background of the Student Thesis, had similarities in the focus and sub-focus under study, namely the coherence in the background of the student's thesis, but differed on the findings. Research Astuti, et al. [1], Found that there are still errors in the theme, the development of research themes that do not change frequently and the level of coherence of writing a background of the thesis is less (less coherence) because of the emergence of other new ideas in one paragraph. Other researchers who study coherence, Liyana [2] have similar subfocuses, about coherence, but differ in research focus, Liyana's [2] research focuses on cohesion and coherence. The findings are related to four things about cohesion and coherence. The findings of these studies include (1) the use of cohesion and conjunction tools, misuse of cohesion tools, (2) only found in reference and conjuncture grammatical cohesion devices, (3) the use of coherence markers, which consist of repetition of keywords, use pronouns, transitional markers and logical sequences in chronology, (4) keyword repeating errors, inconsistent pronominals, transitional markers errors, grammatical errors, and improper use of punctuation are the causes of lack of coherence of thesis, and (5) findings that if in terms of the principles applied in the thesis, it can be said that the thesis of a student is coherent in terms of the use of a concise, round, polite, coherent and objective language. However, it is not coherent in terms of using language that is complete, honest, straightforward, and interesting.

Research Fitriati and Yonata [14] have similarities in research focus and the location of differences exists at the level of coherence. Fitriati and Yonata's [14] research focuses on the level of coherence in the use of conjunctions while this research lies in the use of conjunctions and text structures. In the journal Fitriati and Yonata [14] explained that the level of coherence in the use of conjunctions to make sentences in the text coherent is still less than optimal. Meanwhile Pambudi, Ghasani, and Mawarni [15] examined the object about the relationship of the meaning of words in the conversation of students. Information can be conveyed if there is cohesiveness in the language. This is different from the focus and object examined in this study. Nurfitriani, Bahry, Azwardi [16] have similarities in the coherence subfocus. Nurfitriani, et al. [16], Also examined cohesion while the study was only on the coherence level. In his research found levels of coherence such as: (1) argumentative coherence, (2) ampicative coherence (3) additive coherence, (4) paraphrastic coherence, (5) genericspecific coherence, and (6) coherence of the outcome conditions. Aflahah [17] focuses the object of research on discourse. This clearly becomes a differentiator with the research conducted by the researcher, namely on the background of the student's thesis. Aflahah [17] found the results of the research by explaining about the term coherence which refers to the aspect of speech, how the hidden proposition is concluded to interpret its focus in shaping a discourse. The coherence of a discourse does not only lie in the existence of a cohesion tool. In addition to cohesion tools, there are still many other factors that make coherence possible. Another condition for achieving coherence is that the proposition must be positive. The Aflahah [17] study examines the cohesion tool that has to do with coherence and focuses on discourse that is the difference between what Aflahah [17] and this research are researching, although there are similarities in the coherence subfocus.

Findings of research results in the journal Ifadah and Candra P [18], that the Thesis written by English education students shows a low relationship or coherence between sentences. In one paragraph, some even show no logical relationship at all. Although then it can be explicitly said that the certain and almost certain written are inseparable parts of the thesis itself, because the written works are produced in English, of course the meaning generated will be different when it is intended in the context of the Indonesian language. The Ifadah and Candra P. [18] studies, have similarities in focus and subfocus but differ in findings.

The findings of this study are also different from the research findings of Fengjie, Xiuying, and Chuanze [3], namely on the focus of research on the level of coherence of student essay writing. Fengjie, Xiuying, and Chuanze [3] found that students still could not write sentences effectively. The use of word sequences, pronouns, modifiers, sequence of ideas, sentence subjects, and tenses has not shown any integrated information integration. This is caused by: (1) lack of self-awareness in getting used to writing in English; (2) limited English vocabulary; (3) weaknesses in the use of English grammar; (4) lack of self-awareness to correct and learn from mistakes when writing. Then based on the results of this study, the researchers concluded that although students could express their ideas in written form, they could not write them with effective sentences. 
Related to the genre of text, in descriptive texts, Fitriati and Yonata [14] in argumentative texts show that the ability of students to express ideas of coherence in sentences is still low and also the ability to use cohesion tools is low on average. In terms of cohesive ideas, the relevance and structure of the written text is not in accordance with the structure of the text. The results of the study also showed that the level of coherence was still lacking because it was not optimal in using conjunctions to make sentences in the text coherent. The study of this research is still limited to certain genres and structure of the text and this is what distinguishes it from the research conducted. Paragraphs that have cohesiveness between sentences are said to be good paragraphs. The existence of aspects of unity, description of ideas or topics in paragraphs can be developed in subsequent sentences.

Based on the above research journals and the research findings it can be concluded that students do not yet have a good level of understanding of the use of conjunctions and text structures well. This means that the level of cohesion of writing conducted by students still shows the level that is not good. This means that students have difficulty integrating sentences into full text. The factors causing this disagreement can also be influenced by the ability of students to use English grammar correctly, especially in using conjunction words that are suitable for their function and the unfamiliarity of writing in a scientific writing style even though they know this is important to them.

\section{CONCLUSION}

The findings of the study illustrate that of the six proposals, two thesis proposals that wrote there would be a gap, one proposal that wrote about the significance of the study and two thesis proposals that wrote the formulation of the research problem. Thus the results are obtained that not all student thesis proposals are analyzed in accordance with the above theory. This can be examined, that such conditions are due to students lacking understanding of Academic Writing course material, which is caused by one of them being a relatively short time in studying lecture material. Other causes can be caused by learning that requires objectives to be achieved while students are not ready to apply existing theories by making thesis proposals.

Students do not have a good level of understanding of the use of text structures. This means that the level of cohesion of writing conducted by students still shows the level that is not good. This means that students have difficulty integrating sentences into full text. The factors causing this disagreement can also be influenced by the ability of students to use English grammar correctly, especially in using conjunction words that are suitable for their function and the unfamiliarity of writing in a scientific writing style even though they know this is important to them.

\section{REFERENCES}

[1] Astuti, Yulia Fitri, Fitri Budi Suryani, dan Diah Kurniati, 2010. The Analysis of Coherence in The Background of Skripsi Written by English Education Department Students of Teacher Training and Education Faculty of Muria Kudus University. (Jurnal Sosial dan Budaya, Vol.3 No 2, ) ISSN 19796889 URL: http://jurnal.umk.ac.id/?page_id= 1448

[2] Liyana, Cut Irna, 2013. Kohesi dan Koherensi pada Skripsi Mahasiswa Pendidikan Bahasa Inggris. Electronic Theses \& Dissertations (ETD) Gajah Mada University. URL: http://etd.repository.ugm.ac.id/ index.php?mod=penelitian_detail\&sub=PenelitianDet ail\&act=view\&typ $=h t m l \& b u k u \_i d=62948$

[3] Fengjie, Li. Yuan Xiuying, Zhang Chuanze, 2013. Analysis of the Problemson Coherence in College English Writing: International Journal of Language and Linguistic. Published online December 18, 2014.; 2(6): 387-390. ISSN: 2330-0250 (Print); ISSN 23300221. DOI : $10.11648 / \mathrm{j} / \mathrm{ij} 11 / 20140206.18$. I

[4] Reid, Joy M. 1994. The Process of Paragraph Writing, New Jersey: Prentice Hall Regents,

[5] Zemach, Dorothy E. dan Lisa A. Rumisek, 2005. Academic Writing: From Paragraph to Essay, London: MacMillan,

[6] Emilia, E. 2014. Teaching Writing: Developing Critical Learners. Bandung: Rizki Press.

[7] Anjani Eka Putra. 2018. Kohesi dan Koherensi pada Wacana Stand Up Comedy Perancis dan Indonesia. Jurnal Kawistara. Vol.3 No. 3. https://jur nal.ugm.ac.id/kawistara/article/view/5223/4275

[8] Itaristanti, 2016. Aspek Kohesi Dan Koherensi Dalam Penulisan Karangan Deskripsi yang Disusun Oleh Pembelajar BIPA (Studi Kasus Mahasiswa Thammasat University, Bangkok Pada Program SeaGate UGM Journal Indonesian Language Education and Literature Vol. 2 , No.1, 2016 http://www. syekhnurjati.ac.id/jurnal/index.php/jeill/

[9] Kushartanti, dkk. 2007. Pesona Bahasa: Langkah Awal Memahami Linguistik. Jakarta: PT. Gramedia Pustaka Utama

[10] Tanskanen, Sanna-Kaisa. 2006. Collaborating towards Coherence: Lexical Cohesion in English Discourse, Amsterdam: John Benjamins,.

[11] Behrens, Laurence dan Rosen, Leonard J., 2010. A Sequence for Academic Writing, New York: Pearson Longman,

[12] Winkler, Anthony C. dan MatherellJo Ray. 2012. Writing the Research Paper: A Handbook. Boston: Wadsworth, Cengage Learning,

[13] Suwandi. 2016. Coherence and cohesion: An analysis of the final project abstracts of the undergraduate students of PGRI Semarang. Indonesian Journal of Applied Linguistics. (IJAL). Vol.5 No.2. http://ejournal.upi.edu/index.php/IJAL/article/view/1 349. 
[14] Fitriati, Sri Wuli dan Yonaya, Fadhila. 2017. Examining Text Coherence in Graduate Students of English Argumentative Essay: Case Study. Dialektika. Jurnal Ilmiah Pendidikan Bahasa, Sastra dan Matematika. Arab World English Journal (AWEL) Volume 8 Number 3 September 2017. DOI: https://dx.doi.org/10.24093/awej/vol8no3.17.

[15] Pambudi, Bagus Dwi., Ghasani, Betari Irma., Mawarni, Bety. 2016. An Anlyisis of Coherence in Causal Conservation. The $5^{\text {th }}$ ELTLT International Conference. Proceedings. Unes.

[16] Nurfitriani, Rajab Bahry, Azwardi. 2014. Analisis Kohesi dan Koherensi dalam Proposal Mahasiswa PBSI. ETD Unsyiah. http://etd.unsyiah.ac.id/ index.php? $\mathrm{p}=$ show detail\&id $=24320$

[17] Aflahah, 2012. Kohesi dan Koherensi dalam Wacana, (Okara: Jurnal Bahasa dan Sastra. Vol. 6 No. 1. 2012), ISSN: $\quad 1907-624 X \quad$ (print) 2442-305 X. http://ejournal.stainpamekasan.ac.id/ index.php/okara /article/view/417.

[18] Ifadah, Muhimatul., Budi P., Candra. 2014 Coherence Level Pada Draft Proposal Skripsi Mahasiswa Pendidikan Bahasa Inggris Unimus Prosiding Seminar Nasional dan Internasional Lembaga Penelitian dan Pengabdian Kepada Masyarakat. Jurnal.unimus.c.id/index.php/psn1201 201/article/view. 